Melnychenko Svitlana, Doctor of Sciences (Economics), Professor, Kyiv National University of Trade and Economics,

Kyiv Ukraine ORCID: 0000-0002-5162-6324

Researcher ID: N-9535-2016

Kulyk Mariia,

$\mathrm{PhD}$ in Economics, Associate Professor, Kyiv National University of Trade and Economics,

Kyiv Ukraine

ORCID: 0000-0001-8732-7441

ResearcherID: N-3088-2016

Poltavska Oksana,

$\mathrm{PhD}$ in Economics, Associate Professor, Kyiv National University of Trade and Economics,

Kyiv Ukraine

ORCID: 0000-0002-5285-4302

Researcher ID: N-3064-2016

\title{
INFORMATIONAL IMPERATIVES FORMATION OF REVENUE MANAGEMENT
}

Using the principles of revenue management which are applied in any business environment, the study found that there are statistically significant returns on the RevPAR and occupancy in Ukrainian hotels after implementing the Revenue management system for the period from 2012 to 2017. The implications of this study are important to the hotel managers, including revenue managers, night auditors, restaurant managers and owners because it indicates that there is important to implement dynamic pricing strategy to increase the revenue.

Keywords: revenue, revenue management, hospitality, dynamic pricing strategy, Ukrainian hotels

Мельниченко Світлана, Кулик Марія, Полтавська Оксана. Формування інформаційних імперативів управління доходами.

У статті розглядаються принципи геvепие менеджменту, які застосовуються в готельному бізнесі. Автори аналізують статистичну залежність показників RevPAR i завантаженість в готелях України після впровадження системи геvепие менеджменту за період 2012-2017 роки. Обтрунтовано необхідність використання результатів дослідження в практиці впровадження 
динамічних иінових стратегій менеджерами готелів, в т. ч. геvепие менеджерами, нічними аудиторами, менеджерами ресторанів $i$ власниками бізнесу з метою підвищення доходів.

Ключові слова: дохід, управління доходами, гостинність, динамічна стратегія ціноутворення, украӥнські готелі

Relevance of research topic. The impact of revenue management on the development of Ukrainian hotels has been thinly examined. After the 2014 crisis, the occupancy of hotels was extremely low. It was $25-30 \%$ average occupancy on the market. In 2017, on average, the average occupancy of Ukrainian hotels has already increased. Today, hotels are not the most profitable segment of economics. But hoteliers are convinced that changes in the Ukrainian tourism business make it even more attractive.

Formulation of the problem. The goal of this study is to analyze the dynamics of hotel revenue management development in Ukraine, based on statistical information for period from 2012 to $2017 \mathrm{yy}$, techniques and tools are used to analyze the data from websites of different hotels and to verify the hypotheses.

Analysis of recent researches and publications. Revenue management, also referred to as Yield management, was first widely implemented in the airline industry ${ }^{6}$ and has been a common practice for the hotel industry as well as many other service industries ${ }^{7}$. Based on certain demand forecasting techniques and optimization models, RM has been found to be very effective in generating extra revenue by dealing with diversified and uncertain demand, given a fixed capacity of perishable inventory. Although with a somewhat wider range, a similar result of $1-8 \%$ has been reported for the improvement in profits in the hotel sector ${ }^{8}$. As for RM in the hospitality industry, the study by Anderson and Xie (2010) serves as an excellent source for a summary of its development, while also providing an outline of previous research. Although the practice of RM has become an essential element in the everyday operation of hotels, as highlighted by Shoemaker $(2003)^{9}$, the implementation of RM can have an adverse effect on customers' perceptions of a company and even destroy customer loyalty, the basis for the long-term profitability of a company ${ }^{10}$. Some research work has, however, addressed the negative impact of RM for the hotel industry. For example,

\footnotetext{
${ }^{6}$ Smith, B. C., Leimkuhler, J. F., \& Darrow, R. M. (1992). Yield management at American Airlines. Interfaces, 22, 8-31.

${ }^{7}$ Anderson, C. K., \& Xie, X. (2010). Improving hospitality industry sales: Twenty-five years of revenue management. Cornell Hospitality Quarterly, 51(1), 53-67.

8 Jones, P. (2000). Defining yield management and measuring its impact on hotel performance. In A. Ingold

${ }^{9}$ Shoemaker, S. (2003). Future of revenue management: The future of pricing in services. Journal of Revenue and Pricing Management, 2(3), 271-279.

${ }^{10}$ Rigby, D. K., Reichheld, F., \& Dawson, C. (2003). Winning customer loyalty is the key to a winning CRM strategy. Ivey Business Journal, March/April, 21 -5.
} 
Sheryl Kimes ${ }^{11}$ recently adopted a qualitative approach and interviewed hotel managers to derive a comprehensive summary of the conflicts between relationship management and RM implementation. In another works she has drawn a lot of attention in the research field of the hospitality industry ${ }^{12}$.

Presenting main material. For the first time Revenue Management began to be used in the West in the early 90's in the field of air transportation, and then became relevant in the field of hospitality, and now this technology is actively used in Ukraine and the countries of the former USSR. The history of implementation of hotel revenue management in Ukraine is near five years.

The concept of yield management (revenue management) has gained its popularity until the 1980s and continues to evolve to the present. Improved in geometric progression, computer technology in turn contributes to the further implementation of this approach in the hospitality industry. By its very nature, hotel income management is a systematic (automated) approach to pricing through the management of the inventory of a room suite and the decision to set the price for each room in this stock.

The most important goal of any business is to focus on profit to generate revenue. As a result, «profit» is an important measure of business efficiency. In practice, an enterprise can manage income in different ways. Different customers are willing to pay different prices for using the same amount of resources. Basically, this procedure is called «yield management» also known as «revenue management». According to Sheryl Kimes (2002), this can basically be described as «selling the right product to the right customer at the right time at the right price.» Basically, revenue management helps managers plan the perfect business mix for their business ${ }^{13}$.

By its very nature, hotel income management is a systematic (automated) approach to pricing through the management of the inventory of a room suite and the decision to set the price for each room in this stock. The primary purpose of this approach is to maximize income in any given period of time.

In other words, depending on the projected demand for placement services, there is a constant adjustment of prices reflecting market trends. Thus, the key element of the hotel income management system is the forecasting of demand for future periods.

Moreover, revenue management can control customer demand, although using variable pricing and bandwidth management to increase profitability. According to Christopher Lovelock, Paul Patterson, Rat Walker (2004), there are two major interconnected areas for effective consumer demand management such as pricing and customer service life. For the most part, prices can be fixed or variable. «Fixed price» can be introduced as one price for the same service for all customers at all times and «variable

\footnotetext{
${ }^{11}$ Kimes, S. E., \& Wirtz, J. (2003). Has revenue management become acceptable? Findings from an international

study on the perceived fairness of rate fences. Journal of Service Research, 6, 125-135.

${ }^{12}$ Kimes, S. E. (2011). The future of hotel revenue management. Journal of Revenue and Pricing Management, 10, $62-72$.

${ }^{13}$ Kimes, S. E. (2002). Perceived fairness of yield management. Cornell Hotel and Restaurant Administration Quarterly, 43(1), $22-30$.
} 
price» can explain different prices at different times or for different client segments. Variable pricing helps control the demand for a simple process. This can lead to a reduction in the cost of discounts in the low cost of the hotel for all customers or may be in the form of price discounts for certain types of customers.

Today, Revenue Management practices are increasingly interested in the owners and managers of hotels, including the small numbered stock, but still not all managed to implement revenue management systems. We can say that the market in this direction is only developing. That's why I'm sure that managing profitability - both from the sale of rooms and the provision of additional services, the provision of banquet and meeting rooms, events - will be the main trend of the hospitality industry for many years to come. With the right approach, Revenue Management will take the work to a better level not only the sales or booking department, but the entire hotel complex.

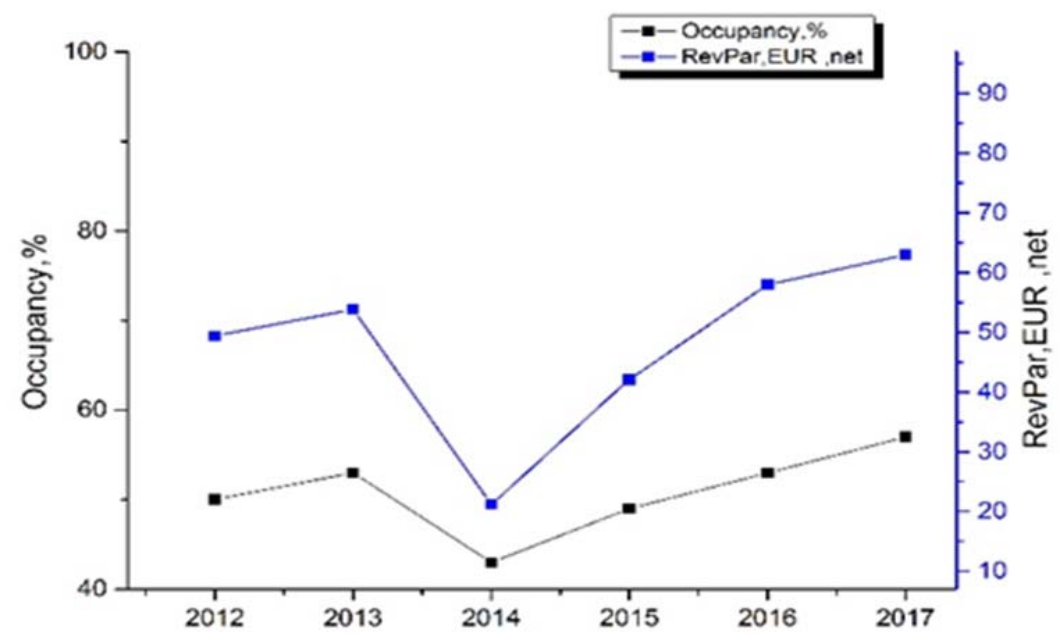

Figure 1. Graphic representation of Occupancy and RevPar dynamics in the Ukrainian hotels

Source: Own development by authors

In figure 1 we can see the positive tendency of increasing of occupancy and RevPar metrics in Ukrainian hotels after the crisis in 2014. Modern circumstances in Ukrainian hotel business require new communication technologies and the new methods of organization and management of the processes. create a technological basis for efficient development in Ukrainian hotels. At the same time in figure 2 we can see the tendency of increasing of ADR in UAH and decreasing of ADR in EUR in Ukrainian hotels after the crisis in 2014. It is appropriate to update the usage of revenue management technologies such as dynamic pricing, segmentation and forecasting demand. Revenue Management in the hotel business is the technology that determines the best price per room based on demand forecasting, that is, the sale of the desired guest room at the right moment at the right price. Revenue Management determines the direction of the sales strategy of the hotel complex.

Principles of revenue management are applied in any business environment. They are great for hotel business. The optimal conditions necessary for introducing income management methods are:

- capacity of sales resources must be fixed - hotels have a fixed number of rooms for sale; Flexible counting of rooms - deviation from the norm; 
- Resources should be considered as perishable products - numbers not sold today can not be sold tomorrow at the expense of the percentage of yesterday's downloads (numbers are sold in advance, before their actual use);

- Demand can be segmented for different markets or by price level.

Hotels that meet all of the above conditions will be able to show better results with revenue management methods. The size and style of the hotel, as well as the market where the hotel operates, will affect the observance of each of these conditions. For example, your market may be limited geographically, or you have to set prices in accordance with the instructions of the government. However, your product will most likely meet at least two of the three requirements outlined above.

To date, in Ukraine there is an obvious tendency to develop this technology not only in network and large hotels, but also in small hotels, where only one employee can handle income control.

If we talk about hotels with a large number of funds, then there, as a rule, there is a department of revenue management, whose employees monitor the changes in prices on the market and conduct an analysis of their own numbers, in order to timely generate the desired price.

For hotels that are just beginning to implement Revenue Management, it is very important in the early stages to correctly identify and shape demand segmentation, which is determined by a combination of factors such as location, list of services provided, competitive environment and price elasticity. For analysis of competitors it is possible and necessary to use widely used tools. It may be such tools as STR, to provide daily reports on the main indicators of the hotel (downloads, average price and profitability of a room) compared with the chosen pool of competitors, as well as to explore open competitor prices in electronic sales channels and various resources for information exchange between hotels.

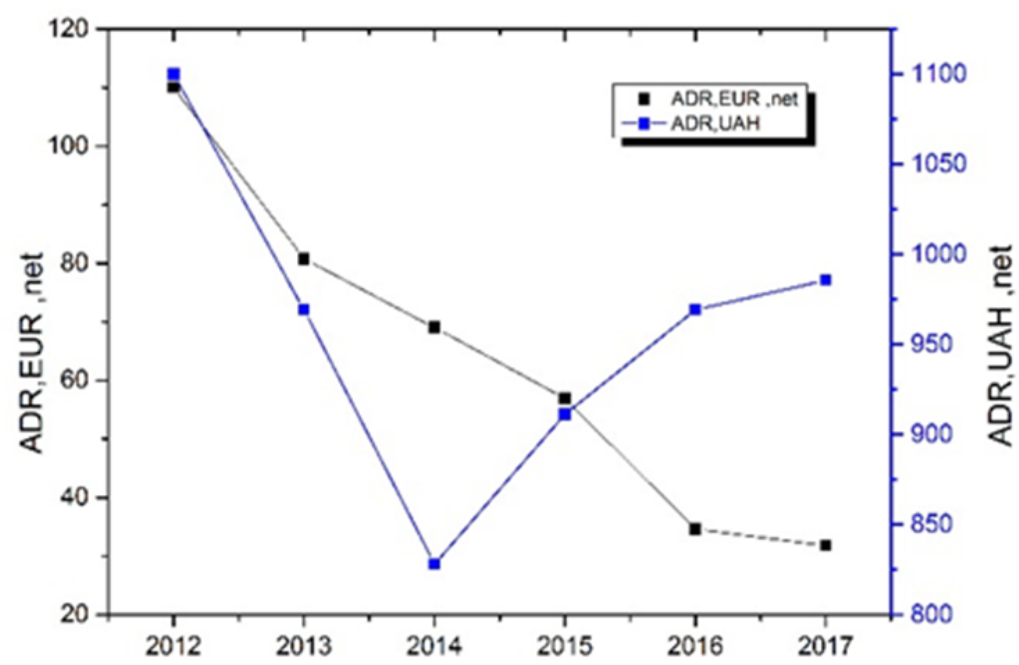

Figure 2. Graphic representation of ADR dynamics in the Ukrainian hotels

Source: Own development by authors/

There are IT solutions to study and shape pricing policies, one of which is the Price Optimizer (Price Optimizer) from YieldPlanet. YieldPlanet Price Optimizer is a 
tool that analyzes the prices of a large number of online resources. This is an ideal solution for hoteliers whose purpose is to form an effective pricing policy for a number fund and business services, based on a thorough analysis of the dynamic pricing policy of all players in the market. The Price Optimizer module gives you the opportunity to not engage in routine work on the analysis of competitor prices and gives more time to make strategic decisions, thereby reducing the cost of human resources.

Conclusion.The system of revenue management allows us to evaluate all aspects of the business activity of the subject of the hotel business, concerning the structure of capital, creditworthiness and other weighty components. On the basis of continuous monitoring of the business environment, organic mastery of strategic thinking and management methods, designed for the future. The modern-day revenge management has a global analytical basis, strategic thinking and management techniques for sales. Therefore, an increase in the level of profitability of an enterprise should be based on a deep financial and economic analysis of the enterprise's activity: an assessment of the technical and economic indicators of the enterprise's activity and the organizational level of production, the use of production capacities and fixed assets, raw materials and labor, economic relations, etc. We can say that the market in this direction is only developing. That's why managing revenue - both from the sale of rooms and the provision of additional services, the provision of banquet and conference rooms, events - will be the main trend of the hospitality industry for many years to come.

\section{REFERENCES}

1. Anderson, C. K., \& Xie, X. (2010). Improving hospitality industry sales: Twenty-five years of revenue management. Cornell Hospitality Quarterly, 51(1), 53-67.

2. Huang, J., Chang, C., \& Chen, C. Y. (2005). Perceived fairness of pricing on the Internet. Journal of Economic Psychology, 26, 343-361.

3. Jones, P. (2000). Defining yield management and measuring its impact on hotel performance. In A. Ingold

4. Kimes, S. E., \& Wirtz, J. (2003). Has revenue management become acceptable? Findings from an international study on the perceived fairness of rate fences. Journal of Service Research, 6, 125-135.

5. Kimes, S. E. (2011). The future of hotel revenue management. Journal of Revenue and Pricing Management, 10, 62 -72.

6. Kimes, S. E. (2002). Perceived fairness of yield management. Cornell Hotel and Restaurant Administration Quarterly, 43(1), 22 -30.

7. Rigby, D. K., Reichheld, F., Dawson, C. (2003). Winning customer loyalty is the key to a winning CRM strategy. Ivey Business Journal, March/April, 21-7.

8. Services marketing: Australia and New Zealand / Christopher H. Lovelock, Paul G. Patterson, Rhett H. Walker. - [Australian ed.] Sydney: Prentice Hall, $570 \mathrm{p}$

9. Shoemaker, S. (2003). Future of revenue management: The future of pricing in services. Journal of Revenue and Pricing Management, 2(3), p. 271-279.

10. Smith, B. C., Leimkuhler, J. F., \& Darrow, R. M. (1992). Yield management at American Airlines. Interfaces, 22, p. 8-31. 